\title{
Genipap flour and its technological potential for food production and manufacturing
}

\author{
Farinha de jenipapo e seu potencial tecnológico para produção e manufatura de alimentos \\ Harina de genipap y su potencial tecnológico para la producción y fabricación de alimentos
}

Received: 10/29/2021 | Reviewed: 11/06/2021 | Accept: 12/06/2021| Published: 12/19/2021

Daniel Rocha Cardoso

ORCID: https://orcid.org/0000-0001-5781-2219

Federal Institute of Education, Science and Technology of Piauí, Brazil

E-mail: Danielrocha@ifpi.edu.br

Fernanda Pereira da Silva Rocha

ORCID: https://orcid.org/0000-0003-2989-870X

Federal Institute of Education, Science and Technology of Piauí, Brazil E-mail: fernanda.silva@ifpi.edu.br

Robson Alves da Silva

ORCID: https://orcid.org/0000-0002-4530-8370

Federal Institute of Education, Science and Technology of Piauí, Brazil

E-mail: robson@ifpi.edu.b

Marcelo Melo Viana

ORCID: https://orcid.org/0000-0001-5946-4553

Federal Institute of Education, Science and Technology of Piauí, Brazil

E-mail: marcelo.viana@ifpi.edu.br

Ayse Suzel Martins Cosme

ORCID: https://orcid.org/0000-0002-5990-0770

Federal Institute of Education, Science and Technology of Piauí, Brazil

E-mail: ayse.martins@ifpi.edu.br

Janiel Costa da Silva

ORCID: https://orcid.org/0000-0002-0876-9311

Federal Institute of Education, Science and Technology of Piauí, Brazil

E-mail: janielcosta007@hotmail.com

Deuzuita dos Santos Freitas Viana

ORCID: https://orcid.org/0000-0002-1902-6505

State University of Maranhão, Brazil

E-mail: deuzuitasfv@gmail.com

Vicente Galber Freitas Viana

ORCID: https://orcid.org/0000-0002-3863-6974

Federal Institute of Education, Science and Technology of Piauí, Brazil

E-mail: galber@ifpi.edu.br

\begin{abstract}
This research aimed to evaluate the technological potential of genipap flour (Genipa americana L.) in freeze drying and oven drying processes. The ripened genipap fruits were harvested and submitted to pulp extraction, which after dehydration in an oven and freeze drying, were crushed to obtain the flours. When analyzed by X-ray diffraction, the flours were amorphous, with indicative of starch. In addition, the presence of water, aromatics and primary alcohols was observed by infrared spectra (FTIR). In micrograph (SEM) FPJDE was less porous and starches were identified. For thermogravimetry (TGA) similar thermal events occurred, it was important to verify the thermal behavior, humidity and ash present in the food. In the mineral composition, potassium, magnesium, manganese, iron, phosphorus, copper, and calcium were present, the flours as a source of manganese and with a high content of iron, potassium, copper and magnesium. It was concluded that the flours present a quantity of nutrients and favorable technological characteristics such as: thermal stability, humidity below that established by law for the manufacture and production of food.
\end{abstract}

Keywords: Genipap flour; Types of drying; Thermogravimetry; Mineral composition.

\section{Resumo}

Esta pesquisa teve como objetivo avaliar o potencial tecnológico da farinha de jenipapo (Genipa americana L.) nos processos de liofilização e secagem em estufa. Os frutos de jenipapo amadurecidos foram colhidos e submetidos à extração da polpa, que após desidratação em estufa e liofilização, foram esmagados para obtenção das farinhas. Quando analisadas por difração de raios- $X$, as farinhas eram amorfas, com indicativo de amido. Além disso, a presença de água, aromáticos e álcoois primários foi observada por espectros de infravermelho (FTIR). Na micrografia (SEM), o FPJDE foi menos poroso e os amidos foram identificados. Para a termogravimetria (TGA) ocorreram eventos térmicos semelhantes, foi importante verificar o comportamento térmico, umidade e cinzas 
presentes nos alimentos. Na composição mineral, potássio, magnésio, manganês, ferro, fósforo, cobre e cálcio estiveram presentes, as farinhas como fonte de manganês e com alto teor de ferro, potássio, cobre e magnésio. Concluiu-se que as farinhas apresentam quantidade de nutrientes e características tecnológicas favoráveis como: estabilidade térmica, umidade abaixo do estabelecido em lei para a fabricação e produção de alimentos.

Palavras-chave: Farinha de jenipapo; Tipos de secagem; Termogravimetria; Composição mineral.

\section{Resumen}

Esta investigación tuvo como objetivo evaluar el potencial tecnológico de la harina de genipap (Genipa americana L.) en procesos de liofilización y secado en horno. Los frutos maduros de genipap fueron recolectados y sometidos a extracción de pulpa, que luego de deshidratación en horno y liofilización, fueron triturados para obtener las harinas. Cuando se analizó por difracción de rayos X, las harinas eran amorfas, con indicativo de almidón. Además, se observó la presencia de agua, aromáticos y alcoholes primarios mediante espectros infrarrojos (FTIR). En micrografía (SEM) FPJDE fue menos poroso y se identificaron almidones. Para la termogravimetría (TGA) ocurrieron eventos térmicos similares, fue importante verificar el comportamiento térmico, la humedad y las cenizas presentes en los alimentos. En la composición mineral estuvieron presentes potasio, magnesio, manganeso, hierro, fósforo, cobre y calcio, las harinas como fuente de manganeso y con alto contenido en hierro, potasio, cobre y magnesio. Se concluyó que las harinas presentan una cantidad de nutrientes y características tecnológicas favorables tales como: estabilidad térmica, humedad por debajo de lo establecido por ley para la fabricación y producción de alimentos.

Palabras clave: Harina de Genipap; Tipos de secado; Termogravimetría; Composición mineral.

\section{Introduction}

Genipap (Genipa americana L.) is a fruit of characteristic flavour and smell, presenting low consumption in natura, however it has been used as raw material for the development of numerous products such as jams, sweets, juices, ice cream, cakes, and flours (Morais et al., 2016; Rinaldi et al., 2010). The processing of vegetable products favours the increase in food production, useful life and avoids waste (Bezerra \& Brito, 2020; Franca et al., 2020; Ribeiro et al., 2016; Figueirêdo et al., 1986).

Some processing improves and preserves the physical, physical-chemical, and nutritional characteristics of foods, based on knowledge of technological characteristics, we can verify factors such as humidity, porosity, loss of mass by heat, cooking temperatures and influences of the composition mineral to produce products from little consumed fruits (Franca et al., 2020; Abrahão et al., 2019; Krumreich et al., 2016). The developed genipap flours represent an alternative for the development of new products, in addition to being a viable solution for the valorization of regional products, both in food processing and in their aggregation to the residues of other fruit pulps (agro-industrial), increasing the nutritional and commercial value of this product (Bezerra \& Brito, 2020; De Sá Mendes, et al., 2020).

Therefore, the use of microscopy, spectroscopy, thermogravimetry and mineral composition made it possible to determine the essential factors for large-scale production, verifying the quality control, processing, and storage of products (Faria et al., 2002). The objective of the research was to analyse the technological characteristics of the flours using the techniques of FTIR, SEM, TG/DrTG and mineral composition of the genipap flours.

\section{Methodology}

This is quantitative experimental research with a survey of numerical data obtained with two types of genipap flours (Dehydrated Pulp Flour in Oven Drying and Lyophilized Genipap Pulp Flour). For this research, 200 genipaps were collected, being selected, and used only a third of them in the preparation and analysis of the flours. In each analysis, five samples of each type of flour were used. All data collected in this study were treated statistically (Pereira et al., 2018; Estrela, 2018).

\section{Botanical aspects}

The botanical material of Genipa americana L., leaves, flowers and / or fruits were collected in the countryside, Vertentes, Piripiri - PI, indicated by the geographical coordinates $4^{\circ} 23^{\prime} 53.3^{\prime \prime} \mathrm{S}$ and $41^{\circ} 46^{\prime} 19.4^{\prime}$ ' W. The samples collected were 
stored in polyethylene plastic bags, sprinkled with $70 \%$ alcohol, stored at a temperature of $20{ }^{\circ} \mathrm{C}$ and transported to the Herbarium Graziela Barroso/University Federal of Piauí (UFPI). The exsiccates of the botanical material were carried out and numbered TEPB: 31,428- Rubiaceae Genipa americana L. on 15 September 2017.

\section{Acquisition of Fruits and Preparation of samples}

The fruits were collected manually at the matured stage, softened, brown in color and with slightly wrinkled skin. The ripened fruits were stored in boxes with anatomical spaces, polyethylene bags and transported to the Laboratory of Technology of Products of Vegetable Origin at the Teresina Central Campus/IFPI, in March 2018. The fruits were cleaned with water and liquid soap, selected, and sanitized by immersion in water with sodium hypochlorite at $50 \mathrm{ppm}$ for 20 minutes. It was destined for pulping, the pulps were packed in polyethylene bags and stored in a freezer at $-17^{\circ} \mathrm{C}$ until the preparation of the flour.

\section{Processing of genipap flour}

From frozen pulps and taken from to thaw. After total thawing, the pulps were weighed and dried for later production of genipap flour, according to the processes below: (a) Drying oven - drying took place in an oven with air circulation at a temperature of $60{ }^{\circ} \mathrm{C}$ for 48 hours (AOAC, 2010). After drying, the sample was reduced to a smaller granule size (disintegrated) in a mortar and underwent grinding in the knife mill, being denominated Genipap Pulp Flour Dehydrated in Drying Oven (FPJDE). (b) Freeze Drying Process - the pulps were weighed and placed in $140 \mathrm{~g}$ plastic containers and frozen for 24 hours in the Liotop ${ }^{\circledR}$ model LT01 freezer at $-80^{\circ} \mathrm{C}$. After freezing, they were submitted to the lyophilization process for 120 hours and at the end of the lyophilization, the sample was reduced to a smaller granule size (disintegrated) in a mortar and underwent grinding in the knife mill, being denominated Freeze-dried Genipap Pulp Flour (FPJL).

\section{X-Ray Diffraction (XRD).}

The device used for the XRD was PANalytical brand from the Federal Institute of Piauí - IFPI, from the laboratory of the master's Program in Materials Engineering, Campus Teresina Central. By developing the best X-ray platform for the analysis of powders, thin films, nanomaterials and solid objects, the X-ray diffractometer with the Empyrean Series 2 as the Xray diffraction system. The data were analyzed using the X'Expert High Score Plus 2.0 program, which contains a database that, by means of comparisons that verify the crystallographic information of the elements contained in the sample and treated in the Origin Pro $8.0 \circledast$ software. The samples were sieved through a 200-mesh sieve, placed in the sample holder, and leveled with a glass slide, after which they were placed for the experiment.

\section{Fourier Transform Infrared Spectroscopy (FTIR)}

The determination of the infrared spectrum was carried out in the chemistry laboratory of the State University of Piaui - UESPI. A sample tablet was made with $\mathrm{KBr}$ (potassium bromide) using a hydraulic press. The material was placed in the Fourier Transform Infrared spectrophotometer (Shimadzu IR Affinity-1 ${ }^{\circledR}$ and IR-solution ${ }^{\circledR}$ software). The measurements were performed in absorbance with a resolution of $4 \mathrm{~cm}^{-1}$ and scanning in the range of $500 \mathrm{~cm}^{-1}$ to $4000 \mathrm{~cm}^{-1}$. The data were treated using the Origin Pro $8.0 ®$ software.

\section{Scanning Electron Microscopy (SEM)}

They were performed in a scanning electron microscope (SEM) of the brand Shimadzu Corporation-Superscan SSX550 SEM-EDX with a voltage of $12-15 \mathrm{kV}$, using the best images as samples. The samples were metallized in the DESK II DENTON VACCUM Metallizer apparatus at the IFPI Materials Engineering laboratory. 


\section{Thermogravimetric analysis (TGA/TG) and derived thermogravimetry (DTGA)}

The thermogravimetric analyzes were performed on the Shimadzu TGA - 51 equipment from the Federal Institute of Piaui - IFPI, from the laboratory of the Program in Materials Engineering, Campus Teresina Central, the TA-WS software of the device itself was used and the data were treated in the same program, 8 to $14 \mathrm{mg}$ of sample was used for the test. The balance was cleaned, calibrated and the sample was then weighed in the platinum crucible, the heating rate of $10^{\circ} \mathrm{C}$ per minute with nitrogen gas flow from $50 \mathrm{~mL} \cdot \mathrm{min}^{-1}$ to $1000{ }^{\circ} \mathrm{C}$.

\section{Mineral Composition}

The samples were weighed with $0.2 \mathrm{~g}$ of the sample and placed in the digestion tubes, $5 \mathrm{ml}$ of the $2: 1$ nitro-perchloric digesting solution were added. The tubes were inserted into the digester block for a period of two hours until reaching $200{ }^{\circ} \mathrm{C}$. After digestion, the extracts were clear and with a volume of approximately $2 \mathrm{~mL}$.

\section{Phosphorus (P)}

The determination of phosphorus was performed by colorimetry, according to the method described by Silva and Queiroz (2002). After the digestion stage, distilled water was added to the extract until it reached $20 \mathrm{~mL}$, after that, the extract was homogenized in a volume of $200 \mu \mathrm{L}$, being transferred to the test tube. $8.4 \mathrm{ml}$ of distilled water, $1 \mathrm{ml}$ of acid ammonium molybdate solution (SAMA) and $400 \mu \mathrm{L}$ of $2 \%$ ascorbic acid solution were added. The extract was prepared and homogenized in a vortex mixer with blue staining and the readings were performed on the BEL Photonics spectrophotometer and model 2000 UV with a wavelength of 725 nanometers, the white reading was performed and at the end it was subtracted from the reading equipment. The absorbance values were calculated in the formula:

$$
\mathrm{P}=(0.2 \mathrm{X} \text { Reading/sample weight }) / 1000
$$

Where the 0.2 of the formula represents the factor obtained from the calibration curve. Phosphorus concentration values were obtained in parts per million (ppm) and then transformed to $\mathrm{mg} \cdot 100 \mathrm{~g}^{-1}$.

\section{Potassium (K) and Sodium (Na)}

After digestion, distilled water was added to the extract until it reached $20 \mathrm{ml}$, and then homogenized. $2 \mathrm{~mL}$ of extract was removed and placed in the test tube along with $2 \mathrm{~mL}$ of distilled water, with the second homogenization, after which the reading was carried out on the flame photometer of the Micronal brand and model 906 AA, with calibration with standard solutions and the values of $\mathrm{K}$ and $\mathrm{Na}$ concentrations were obtained in parts per million (ppm) and transformed to $\mathrm{mg} .100 \mathrm{~g}^{-1}$.

\section{Calcium (Ca) and Magnesium (Mg)}

After digestion, distilled water was added to the extract to $20 \mathrm{~mL}$ and homogenized. The volume of $200 \mu \mathrm{L}$ of the homogenized extract was measured and transferred to the test tube, where $3.5 \mathrm{ml}$ of lanthanum and $3.3 \mathrm{ml}$ of distilled water were added, homogenization and reading in the atomic absorption spectrum was performed, GBC brand and model B462, the element to be analyzed in the equipment program was previously indicated. The values of $\mathrm{Ca}$ and $\mathrm{Mg}$ were obtained in parts per million (ppm) and transformed to $\mathrm{mg} \cdot 100 \mathrm{~g}^{-1}$. 


\section{Iron (Fe), Manganese (Mn) and Copper $(\mathrm{Cu})$}

Distilled water was added to the extract up to $20 \mathrm{~mL}$, then it was homogenized and the reading on the atomic absorption spectrophotometer, brand GBC, model B462, was selected in advance in the equipment the specific wavelength for each element. The values of the concentrations of $\mathrm{Fe}, \mathrm{Mn}$ and $\mathrm{Cu}$ were obtained in parts per million (ppm) and transformed to mg. $100 \mathrm{~g}^{-1}$.

\section{Statistical Analysis}

The data obtained were analyzed by the SPSS program, using the levene F test with the student's $\mathrm{T}$ test among the independent variables. There was a significant difference between treatments, with an interval of $5 \%$.

\section{Results}

The XRD analysis is important to relate the structure of the food, as the beam intensity and the angles found in the diffractogram indicate the crystallinity of the sample, including the behavior of the material and its crystalline structure (Zuidam \& Nedovic, 2012). The FPJDE and FPJL diffractogram found that the samples showed a disorganization in their structure, predominantly amorphous, with poorly defined peaks in the diffractor (Barros et al., 2021; Cheriegate, 2012) (Figure 1).

Figure 1. Black: Freeze-dried Genipap Pulp Flour (FPJL) and Blue: Genipap Pulp Flour Dehydrated in Drying Oven (FPJDE).

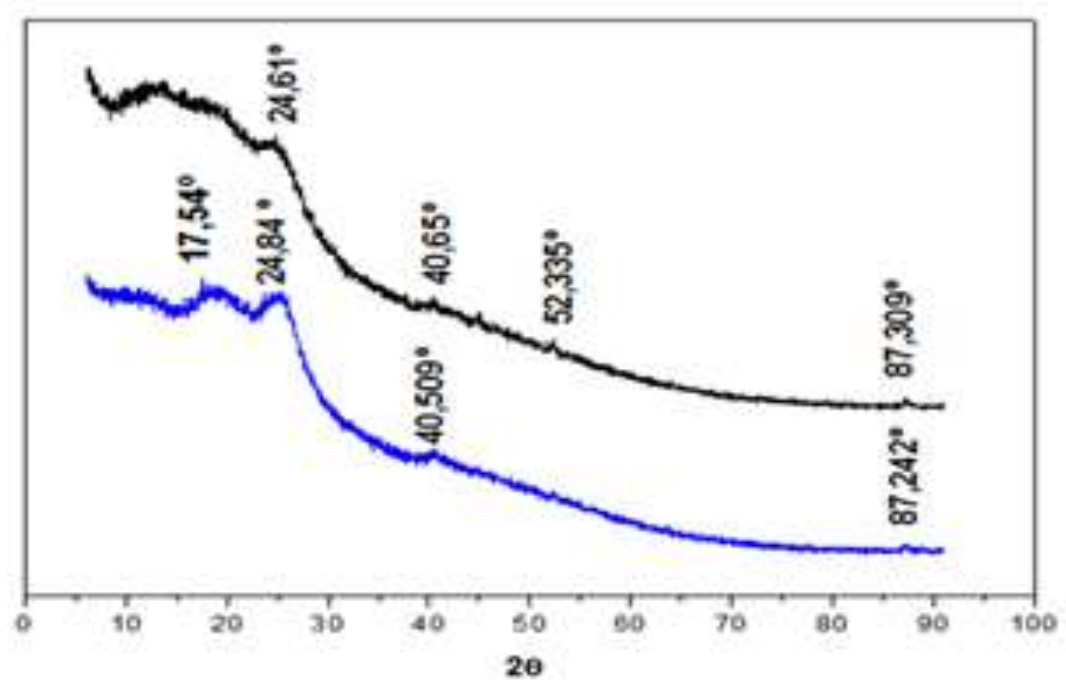

Source: Authors (2019).

The FTIR of FPJDE and FPJL obtained similar aspects, however the intensity between the peaks was different and the results are shown in Figure 2. Some morphological and functional characteristics of genipap flour are visualized in these micrographs (SEM), presented in Figure 3. The micrographs show structures with thin and elongated thicknesses, which are related to the plant cell (starch) wall in Figure 3 (Barros et al., 2018; Moura, 2016). The micrographs of Figures 3(c) and 3(d) show porosity of the flour, indicating its water absorption and hygroscopicity. 
Figure 2. Black: Freeze-dried Genipap Pulp Flour (FPJL) and Blue: Genipap Pulp Flour Dehydrated in Drying Oven (FPJDE).

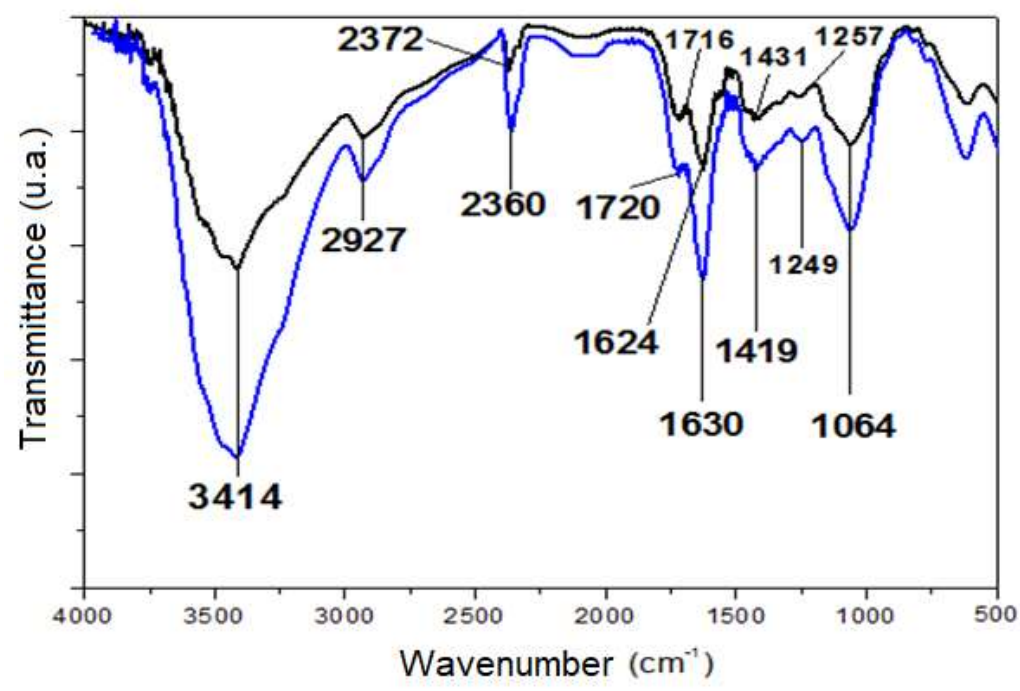

Source: Authors (2019).

Figure 3. (a) increased 1000 times indicate elongated cells and greater roughness in Freeze-dried Genipap Pulp Flour (FPJL). (b) increased 1000 times indicates the presence of starch in Genipap Pulp Flour Dehydrated in Drying Oven (FPJDE). (c) increased 200 times indicate greater porosity Freeze-dried Genipap Pulp Flour (FPJL). (d) increased 1000 times indicate less porosity in Genipap Pulp Flour Dehydrated in Drying Oven (FPJDE).
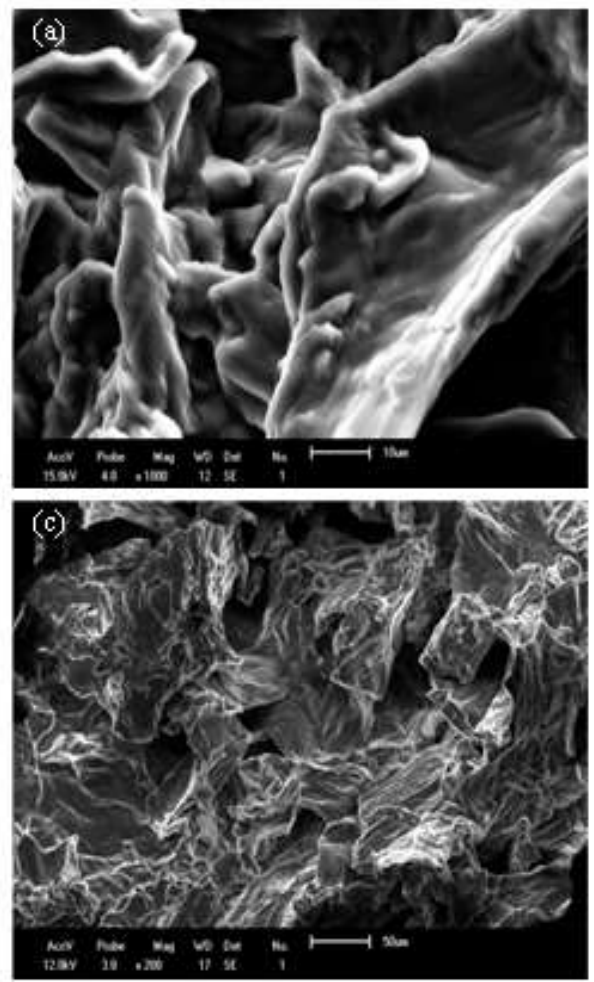
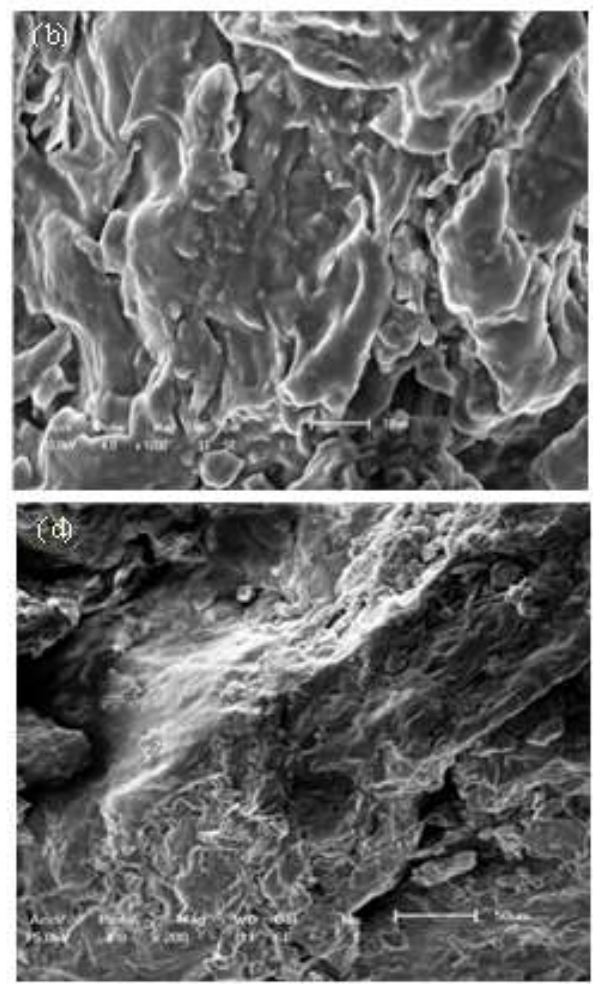

Source: Authors (2019).

The TGA/DrTGA(DTG) curves characterize the variations in temperatures and mass, with the area on the DrTGA curve referring to the lost mass, where the peak height provides the variation in mass at a given temperature (Carli, 2017; Araújo et al., 2006). The results of mass losses and temperature peaks occurred very similarly in the thermogravimetric 
analyzes and are shown in figures 4 and 5. For FPJDE (Figure 7) and FPJL (Figure 8) showed four (4) mass losses or events without a period of stability between them (Table 1).

Table 1. Thermogravimetry (TG and DTG) results of FPJDE and FPJL.

\begin{tabular}{lcccc}
\hline Samples & Thermal Event & $\Delta \mathrm{m}(\%)$ & $\Delta \mathrm{T}\left({ }^{\circ} \mathrm{C}\right)$ & $\mathrm{Tp}\left({ }^{\circ} \mathrm{C}\right)$ \\
\hline FPJDE & 1 & 7.24 & $25.0-135.0$ & 70.9 \\
& 2 & 24.40 & $135.0-252.1$ & 206.5 \\
& 3 & 29.52 & $252.1-412.7$ & 324.4 \\
& 4 & 33.42 & $412.7-597.3$ & 518.8 \\
\hline FPJL & 1 & 6.31 & $25.0-123.0$ & 67.6 \\
& 2 & 28.1 & $123.0-253.1$ & 210.2 \\
& 3 & 28.5 & $253.1-415.3$ & 310.9 \\
& 4 & 32.7 & $415.3-584.7$ & 512.3 \\
\hline
\end{tabular}

Legend: $\Delta \mathrm{m}(\%)$ loss of mass, $\Delta \mathrm{T}\left({ }^{\circ} \mathrm{C}\right)$ temperature range, $\mathrm{Tp}\left({ }^{\circ} \mathrm{C}\right)$ peak temperature. Source: Authors $(2019)$.

Figure 4. FPJDE (black box): $\Delta \mathrm{m}(\%)$ - loss of mass (\% and $\mathrm{mg}$ ) and (blue box): temperature and $\%$ of the remaining sample.

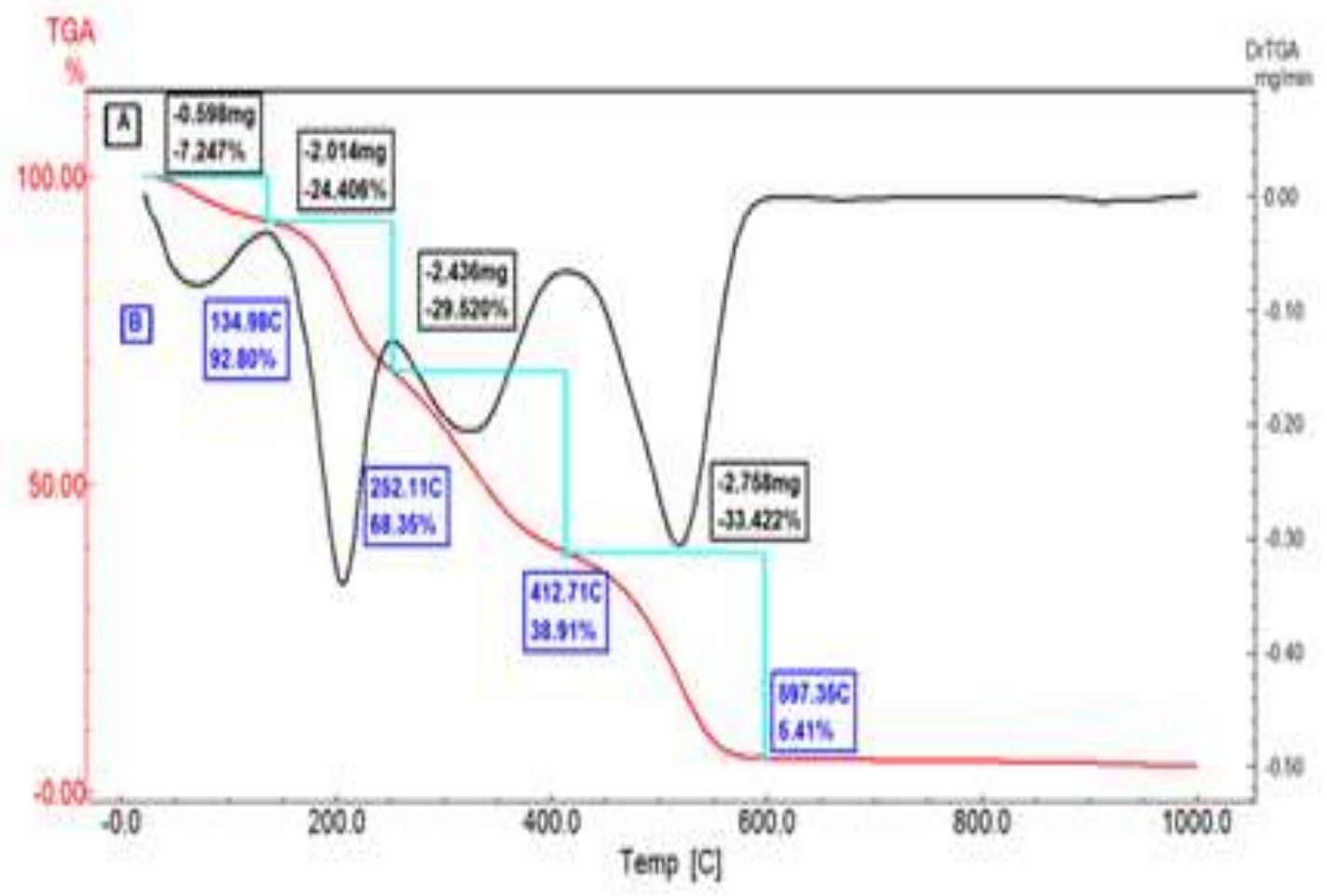

Source: Authors (2019). 
Figure 5. FPJL (black box): $\Delta \mathrm{m}(\%)$ - loss of mass (\% and $\mathrm{mg}$ ) and blue box): temperature and $\%$ of the remaining sample.

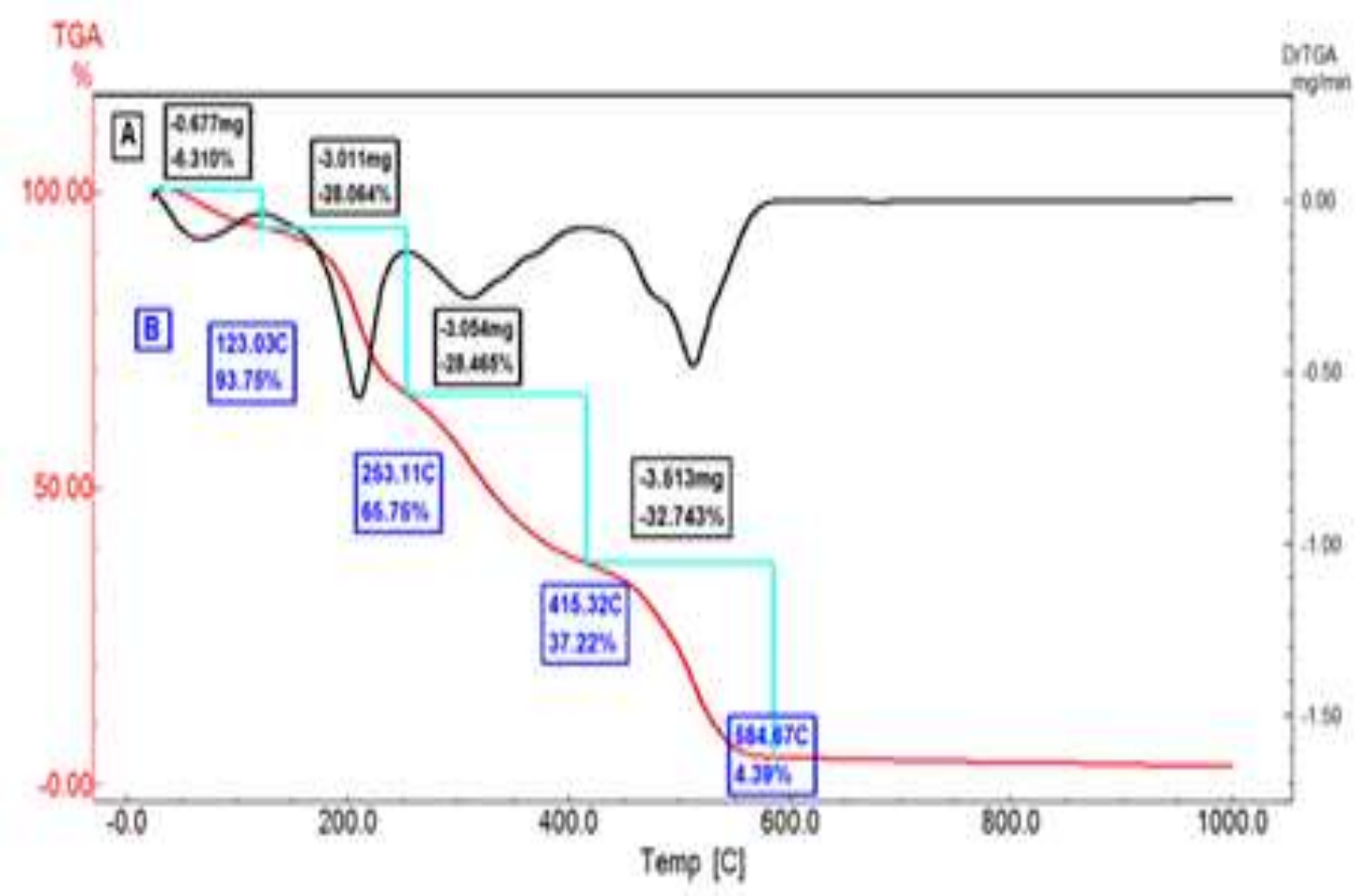

Source: Authors (2019).

Table 2 shows the results of minerals, the elements manganese $(\mathrm{Mn})$, calcium $(\mathrm{Ca})$ and magnesium $(\mathrm{Mg})$, there was no statistical difference, however for iron $(\mathrm{Fe})$, phosphorus $(\mathrm{P})$ and potassium $(\mathrm{K})$ there was statistical difference between the treatments in the studied flours, the presence of sodium $(\mathrm{Na})$ was not identified in the samples. The reference values for the results of minerals were based on Brazilian legislation for the adult population (BRASIL, 2012; BRASIL, 2005).

Table 2. Mineral composition of genipap flours.

\begin{tabular}{lcccc}
\hline \multicolumn{1}{c}{ Mineral/unity } & FPJDE $(\%)$ Mean and & FPJL (\%) Mean and & \multicolumn{2}{c}{ IDR (\%) } \\
& standard deviation & standard deviation & FPJDE & FPJL \\
\hline Fe $(\mathrm{mg} / 100 \mathrm{~g})$ & $4.32 \pm 1.47^{\mathrm{a}}$ & $0.86 \pm 0.10^{\mathrm{b}}$ & 30.71 & 6.12 \\
$\mathrm{Mn}(\mathrm{mg} / 100 \mathrm{~g})$ & $0.47 \pm 0.40^{\mathrm{a}}$ & $0.35 \pm 0.13^{\mathrm{a}}$ & 20.43 & 15.35 \\
$\mathrm{Ca}(\mu \mathrm{g} / 100 \mathrm{~g})$ & $56.00 \pm 0.05^{\mathrm{a}}$ & $50.00 \pm 0.07^{\mathrm{a}}$ & 5.60 & 5.00 \\
$\mathrm{Cu}(\mu \mathrm{g} / 100 \mathrm{~g})$ & $799 \mu \mathrm{g} \pm 0.26^{\mathrm{a}}$ & $561 \mu \mathrm{g} \pm 1.13^{\mathrm{a}}$ & 88.70 & 62.30 \\
$\mathrm{Mg}(\mathrm{mg} / 100 \mathrm{~g})$ & $116.00 \pm 0.09^{\mathrm{a}}$ & $116.00 \pm 0.11^{\mathrm{a}}$ & 44.61 & 44.61 \\
$\mathrm{P}(\mathrm{mg} / 100 \mathrm{~g})$ & $85.00 \pm 0.05^{\mathrm{b}}$ & $98.00 \pm 0.02^{\mathrm{a}}$ & 12.14 & 14.00 \\
$\mathrm{~K}(\mathrm{~g} / 100 \mathrm{~g})$ & $1.58 \pm 0.20^{\mathrm{b}}$ & $1.80 \pm 0.62^{\mathrm{a}}$ & 33.62 & 38.23 \\
\hline
\end{tabular}

Legend: Different letters ${ }^{a}$, $b$ in the lines show statistically significant differences $(p \leq 0.05)$. FPJDE: Genipap Pulp Flour Dehydrated in Drying Oven. FPJL: Freeze-dried Genipap Pulp Flour. IDR: Recommended Daily Intake. Source: Authors (2019).

\section{Discussion}

Despite the different drying methods, in the drying oven and freeze drying, there were similarities in the flour diffractograms (Figure 1), there was the preservation of starches in FPJDE (Figure 4), however in FPJL the presence of 
starches was not verified (Figure 3(a)), having a characteristic more "amorphous", due to the drying process, the grinding of the sample, moisture, temperature and the pressure that was submitted (Barros et al., 2018).

Another important aspect to assess the crystalline or amorphous condition of the material is the difference in the peak intensity (Caparino et al., 2012), the less intense the peaks, the more amorphous the material, this small difference was perceived in the diffractogram in that flours (Figure 1). However, many low-intensity noises and spikes were observed with angles of approximately $24.61^{\circ}$ for FPJL (Figure $1 \mathrm{~A}$-black), $17.54^{\circ}$ and $24.84^{\circ}$ for FPJDE (Figure 1B-blue), indicating the presence of type B starches found in fruits, which present in their diffractograms angles close to $5.6^{\circ}, 14.4^{\circ}, 17.2^{\circ}, 22.2^{\circ}$ and $24^{\circ}$ (Barros et al., 2021; Brancalione, 2021; Barros et al., 2018; Lima et al., 2012).

The amorphous characteristic is predominant in the genipap flours developed in this research, indicated by the concentration of sugars that oxidize and cause the flours to change colour over time, drying temperature, hygroscopicity and solubility (Caparino et al., 2012). Solubility is a reliable parameter to analyse powder behaviour in aqueous solution. Higher solubility is desirable especially when the powder obtained is used as an additive in the production of products (Tontul \& Topuz, 2017). The properties of the powders, such as moisture content, particle size and crystalline structure, influence solubility, the more amorphous the material, the more soluble the sample will be (Tontul \& Topuz, 2017).

In the FTIR (Figure 2), a rounded peak was observed in the band close to $3400 \mathrm{~cm}^{-1}$, indicating the presence of a strong band characteristic of hydroxyls $(\mathrm{OH})$, present in the D-glucose of starches from different origins and sources with the presence of water (Silva et al., 2021; Barros et al., 2018; Melo Neto et al., 2016; Tavares et al., 2011). In the region of the spectrum between $2842-3000 \mathrm{~cm}^{-1}$, the presence of methyl and methylene C-H group stretching present in lignin was noticed. The bands found in the FPJDE and FPJL were 1624 and $1627 \mathrm{~cm}^{-1}$, respectively, contained in the band between 1653 and 1586 $\mathrm{cm}^{-1}$ and identified as deformed aromatic nuclei, attributed to the $-\mathrm{CONH} 2$ (amide) stretch, the presence of $\mathrm{C}=\mathrm{C}$ of $\mathrm{COOH}$ (carboxylic acid) of aromatics with intense vibrations ( Silva et al., 2021; Barros et al., 2018; Carli, 2017) .

At approximately 1628 and $1630 \mathrm{~cm}^{-1}$, this band indicates the amorphous phase of cellulose, which is represented by the peaks of $1624 \mathrm{~cm}^{-1}$ for FPJL and $1631 \mathrm{~cm}^{-1}$ in FPJDE (Barros et al., 2021; Rambo \& Ferreira, 2015). The spectrum region from 1300 to $900 \mathrm{~cm}^{-1}$ presented for the two flours (FPJDE and FPJL), coupled and low intensity peaks, indicating CO of aromatic ethers that represent the basic characteristics of genipap, in case there is a significant difference in this region of the spectrum, this will be an indication of product adulteration (Silva et al., 2021; Barros et al., 2018; Carli, 2017). Around 1200$1050 \mathrm{~cm}^{-1}$, the bands are related to the vibrations of COC (ether) deformation of the glycosidic bond, the $\mathrm{C}$ (carbon) of $\mathrm{OH}$ elongation forming primary alcohol, in the axial formation vibrations of the OCO (acid) system and phenols, it is also the band that characterizes the starch sample and its origin (Monteiro et al., 2015; Lima et al., 2012; Tavares et al., 2011).

Analyzing Figure 3(b), it was noticed the presence of starch in the micrograph of FPJDE, since in foods of plant origin the starches have rounded granules with sizes that differ for each species studied, being responsible for the structure, texture and consistency (Asquieri, et al., 2020; Silvio et al., 2020; Leonel, 2007). Therefore, starch has different economic potential and can be used to replace fats (starches with smaller granules), in the production of bioplastics and biofilms (starches with larger granules) ( Leonel, 2007).

The micrograph in the Figure 3(c) (FPJL), which presented a greater number of cavities or pores, a factor that facilitates the fluidity and rehydration of the product after water loss, explained by the solid state of the water present in the sample in moment of lyophilization, because when going through the sublimation process, occurring at low temperature and pressure, it preserves the sample structure without losing its shape and volume (Cesar et al., 2021; Alves \& Ascheri, 2016; Zartorelli, 2014; Ratti, 2001). The opposite occurred in Figure 3(d) (FPJDE) presents a smoother appearance with less porosity, aspects that indicate less water absorption and hygroscopicity, presenting itself in a more integral way with regard to its structure (Alves \& Ascheri, 2016 ; Zartorelli, 2014; Zhang, P., \& Hamaker, B. R. 2012; Ratti, 2001). 
The influence of reducing sugars was verified in the lyophilized (Figure 5), indicating greater porosity and hygroscopicity in FPJL, different from FPJDE that the increase in temperature in the drying process causes molecular disorganization, causing changes in polarity and conformation of the samples due to -OH sites, due to the removal of water and the oxidation of reducing sugars (glucose and fructose), reducing the possibility of water adsorption and justifying the lower moisture and lower rate of vitamin C degradation in FPJDE (Goula \& Adamopoulos, 2006).

The study of the flour's morphology through SEM, FTIR and the knowledge of the characteristics of the granules allow to elucidate its origin, being of great value in verifying adulterations of food, indicating a mixture of ingredients not recommended or prohibited by law, besides verifying technological and functional properties of food (Bezerra, 2010).

In the $1^{\text {st }}$ thermal event or loss of mass in Thermogravimetry (TGA), water and volatile compounds in the sample are lost with $\Delta \mathrm{m}(\%)$ of 7.24\% FPJDE (Figure 7) and 6.31\% for FPJL (Figure 5), with temperature between 25 and $134{ }^{\circ} \mathrm{C}$ and indicate the different degrees of hydration of the flours, since moisture is important for the quality of the product, stability and composition, avoiding values above $15 \%$ of moisture (Silva et al., 2021; Almeida et al., 2020). This is necessary to obtain microbiological control in processed products (Abud \& Narain, 2010).

According to Kebelmann, Hornung, Karsten and Griffiths (2013) in the study of green algae, $2^{\text {nd }}$ loss indicates the decomposition of carbohydrates and other organic compounds, between 123 and $253{ }^{\circ} \mathrm{C}$ with $\Delta \mathrm{m}(\%)$ of $24.40 \%$ (FPJDE) and $28,06 \%$ (FPJL), there is a greater loss of mass in the FPJL that occurred between 170 and $250{ }^{\circ} \mathrm{C}$, explained by the higher concentration of lipids in this flour. Thermal events are explained by the degradation of polysaccharides (Table 1, Figures 4 and 5), with depolymerization occurring when the temperature exceeds $300{ }^{\circ} \mathrm{C}$ and the formation of carbonic groups. (CO and $\mathrm{CO}_{2}$ ) (Souza \& Silva, 2021; Almeida et al., 2020; Carli, 2017; Lima et al., 2012).

The $3^{\text {rd }}$ mass loss was related to the formation of carbonaceous with $\Delta \mathrm{m}(\%) 29.52 \%$ (FPJDE) and 28.46\% (FPJL), with a temperature range in this thermal event of 252 to $415^{\circ} \mathrm{C}$, indicating the degradation of biomass lignin and cellulose the flours, with the decomposition of hemicellulose (250 to $\left.290{ }^{\circ} \mathrm{C}\right)$, cellulose $\left(340\right.$ to $360{ }^{\circ} \mathrm{C}$ ) and lignin (above $\left.400{ }^{\circ} \mathrm{C}\right)(\mathrm{Rambo}$ et al., 2015). Mass loss is explained by the degradation of polysaccharides, with depolymerization occurring when the temperature exceeds $300{ }^{\circ} \mathrm{C}$ and the formation of carbonic groups (CO and CO2) (Souza \& Silva, 2021; Almeida et al., 2020; Carli, 2017; Lima et al., 2012).

According to the studies by Silva et al., (2021) and Rambo et al., (2015) in the $4^{\text {th }}$ stage, there is the formation of ashes between 400 and $600{ }^{\circ} \mathrm{C}$, corresponding to the degradation of carbonaceous, with $\Delta \mathrm{m}(\%)$ of 32.74\% (FPJDE) and $33.42 \%$ (FPJL), ash formation occurred in flours with approximately $600{ }^{\circ} \mathrm{C}$, ending the thermal events and remaining in the samples the carbonates, silicates and sulfates that have melting points above $600^{\circ} \mathrm{C}$ (Figures 4 and 5).

Based on the studies by Araújo et al., (2006) and Silva et al., (2001), they found that the proximity between the results obtained in traditional methodologies and thermogravimetry (TGA), can influence the use of TGA as a methodology for characterization of moisture and ash in food, because of the precision of the results, less amount of sample used and less time spent during the analysis, in addition to observing the thermal events that occurred with the sample without interference during the process, identifying the thermoanalytical profile, checking the temperature which sample can be used in food preparation and production.

From the thermal analysis, the use of these methodologies (TG/DrTG) was essential, with the possibility of using the flours in food, cosmetics, pharmaceuticals, polymers and others (Faria et al., 2002). The results for iron (Fe) were 4.31 $\mathrm{mg} / 100 \mathrm{~g}$ for FPJDE and $0.86 \mathrm{mg} / 100 \mathrm{~g}$ for FPJL, with statistical difference $(\mathrm{p} \leq 0.05)$. FPJDE has a high content of this mineral, with around $30.7 \%$ of the IDR (BRASIL, 2012; BRASIL, 2005) and its value was higher than that of raw cassava flour $(1.1 \mathrm{mg} / 100 \mathrm{~g})$, roasted cassava $(1.2 \mathrm{mg} / 100 \mathrm{~g})$ and puba flour $(1.4 \mathrm{mg} / 100 \mathrm{~g})$ (TACO, 2011). 
It presented values for Fe higher than the genipap pulps with $0.22 \mathrm{mg} / 100 \mathrm{~g}$ (De Souza et al., 2012) and from 0.28 to $0.37 \mathrm{mg} / 100 \mathrm{~g}$ (Souza, 2007). The intake of this mineral is essential because it participates in the transport of oxygen, the synthesis of hemoglobins, muscle fibers (myoglobin) and mitochondrial enzymes (Verna et al., 2021; Torres, et al., 2020).

The values of manganese $(\mathrm{Mn})$ were $0.470 \mathrm{mg} / 100 \mathrm{~g}$ in FPJDE and $0.353 \mathrm{mg} / 100 \mathrm{~g}$ in FPJL, there was no statistical difference between the processing, with a percentage of adequate for daily intake of $20.43 \%$ for drying oven and $15.35 \%$ for lyophilized, considering flour as a source of this mineral (BRASIL, 2012; BRASIL, 2005), it is worth mentioning that manganese helps in the regulation processes of amino acids, cholesterol, in the formation of bone and connective tissue (Borges et al., 2003).

For copper $(\mathrm{Cu})$, there was no statistical difference, the levels were $799 \mu \mathrm{g} / 100 \mathrm{~g}$ (FPJDE) and $561 \mu \mathrm{g} / 100 \mathrm{~g}$ (FPJL) with results of $88.7 \%$ (FPJDE) and 62.3\% (FPJL) in relation to IDR, presenting with high mineral content and of extreme relevance, since it acts in the transfer of electrons, in the homeostasis of the human body, in the defense against free radicals, in the synthesis of melanin and directly contributing to the metabolism of the human body (Arendsen et al., 2021; BRASIL, 2012; BRASIL, 2005).

The flours studied showed Ca (calcium) contents of 0.56 and $0.50 \mathrm{mg} / 100 \mathrm{~g}$, with IDR percentages of $5.6 \%$ and $5 \%$ for FPJDE and FPJL, respectively, with no statistical difference between treatments, values below of genipap flour with 417.57 $\mathrm{mg} / 100 \mathrm{~g}$ and green banana flour with $130 \mathrm{mg} / 100 \mathrm{~g}$ (Borges et al., 2009) Calcium (Ca) is a mineral that is part of bone formation and transmission of nerve impulses (Bergwitz et al., 2021; Borges et al., 2003).

As for magnesium $(\mathrm{Mg})$, the flours studied obtained levels of $116 \mathrm{mg} / 100 \mathrm{~g}$ in this research, with no statistically significant difference, representing $44.6 \%$ of the IDR, meaning a high content of $\mathrm{Mg}$, having nutritional importance, acting on enzymes and ion exchanges between cell membranes (Schutten et al., 2021; BRASIL, 2012; BRASIL, 2005; Borges et al., 2003).

The levels (Mg) obtained in the present study are higher than those of commercial açaí flour (33.04 mg/100g), plum (36.12 mg/100g), green banana $(36.12 \mathrm{mg} / 100 \mathrm{~g})$, coconut $(20.43 \mathrm{mg} / 100 \mathrm{~g})$, passion fruit $(86.09 \mathrm{mg} / 100 \mathrm{~g})$ and close to the commercial grape flour (122.01 mg/ 100g) of the study by Carli (2017).

The levels for phosphorus (P) were $85 \mathrm{mg} / 100 \mathrm{~g}$ for FPJDE and $98 \mathrm{mg} / 100 \mathrm{~g}$ for FPJL, with statistical difference $(\mathrm{p} \leq 0.05)$, representing between $12.14 \%$ and $14 \%$ of the recommended daily intake (IDR), respectively (BRASIL, 2012; BRASIL, 2005). These values are close to potato peel flour with $90 \mathrm{mg} / 100 \mathrm{~g}$ (Fernandes et al., 2008; Fernandes, 2006) and guava peel flour between 72 and $90 \mathrm{mg} / 100 \mathrm{~g}$ (Moura, 2016), this mineral has an influence on the energy supply for people cells and the formation of phospholipids (Bergwitz et al., 2021; Borges et al., 2003).

For K, results of 1,582 mg/100g (FPJDE) and 1,796 mg/100g (FPJL) were observed, with the respective values (IDR) of $33.62 \%$ and $38.23 \%$ for FPJDE and FPJL, with statistical difference $(p \leq 0.05)$ between the flours. Potassium is important in food, as it acts on muscle contraction and cardiac function (Stone et al., 2021; Borges et al., 2003). The results for K were higher than those found for genipap in natura in other studies, with $92.55 \mathrm{mg} / 100 \mathrm{~g}$ (De Souza et al., 2012) and 1,003 mg/100g (Oliveira et al., 2006) and in flour by genipap de Ribeiro et al., (2016) with a value of 1,395 mg/100g.

\section{Conclusion}

In reference to the technological aspects of flour, in the FTIR the flours are amorphous. Microscopy showed a greater presence of pores in the FPJL, which indicates greater hygroscopicity and moisture, for FPJDE the presence of starch. By thermal analysis, it was found that there is a preservation of more than $66 \%$ of the sample up to a temperature of $250{ }^{\circ} \mathrm{C}$, allowing the use of flour. In bakery products (breads and cakes). The mineral composition presents flour as a source of Mn and a high content of $\mathrm{Cu}, \mathrm{Fe}, \mathrm{Mg}$ and $\mathrm{K}$, important minerals for the functioning of the human organism. 
It is suggested that further studies be carried out to demonstrate the bioactive compounds, solubility in water and oil, absorption capacity and viscosity of genipap flour, important technological aspects for the creation and elaboration of new food products.

\section{Acknowledgments}

I thank my advisors, prof. Dr. Vicente Galber Freitas Viana and prof. Dr. Robson Alves da Silva. To Mr. Luís Joaninha who supported us in the collection and transport of research material. To the Federal Institute of Science and Technology of Piauí-IFPI in the Materials Engineering Program-PPGEM. To the technicians of the PPGEM laboratories, chemistry and food technology who helped in the experiments.

\section{References}

Abrahão, F. R., Rocha, L. C. R., Santos, T. A., Carmo, E. L. do, Pereira, L. A. S., Borges, S. V., Pereira, R. G. F. A., \& Botrel, D. A. (2019). Microencapsulation of bioactive compounds from espresso spent coffee by spray drying. LWT, 103. https://doi.org/10.1016/j.1wt.2018.12.061

Abud, A. K. de S., \& Narain, N. (2010). Incorporação da farinha de resíduo do processamento de polpa de fruta em biscoitos: uma alternativa de combate ao desperdício. Brazilian Journal of Food Technology, 12(4), 257-265. https://doi.org/10.4260/BJFT2009800900020

Almeida, R. L. J., Santos, N. C., Pereira, T. dos S., Pinheiro, W. S., Silva, V. M. de A., Barros, E. R., Muniz, C. E. de S., Medeiros, M. S. de, Miranda, D. S. do A., \& Cavalcante, J. de A. (2020). Thermal analysis of japonica rice starch submitted to different types of milling. Research, Society and Development, 9(3), e30932326. https://doi.org/http://dx.doi.org/10.33448/rsd-v9i3.2326

Alves, P. L. da S., \& Ascheri, J. L. R. (2016). Análise por imagem e microscopia eletrônica por varredura das farinhas extrudadas de arroz e maracujá. Higiene Alimentar, 30(258/259), 144-148,jul./ago.

AOAC. Official methods of analysis of the Association of Official Analytical Chemistry. 16 ed. Arlington: Washington, 2010.

Araújo, A. A. de S., Mercuri, L. P., Ricardo, S. S. S., \& Matos, J. do R. (2006). Determinação dos teores de umidade e cinzas de amostras comerciais de guaraná utilizando métodos convencionais e análise térmica. Revista Brasileira de Ciências Farmacêuticas, 42(2), 269-277,abr./jun.

Arendsen, L. P., Thakar, R., Bassett, P., \& Sultan, A. H. (2021). A double blind randomized controlled trial using copper impregnated maternity sanitary towels to reduce perineal wound infection. Midwifery, 92, 1028. https://doi.org/10.1016/j.midw.2020.102858

Asquieri, E. R., Nishi, A. C. F., Batista, R. D., \& Asquieri, E. M. de A. R. (2020). Yacon extract drying (Smallanthus sonchifolius) by Spray Dryer: effect of the different carrier agents and evaluation of the levels of frutooligosaccharides and phenolic compounds. Research, Society and Development, 9(7), 1-26. https://doi.org/http://dx.doi.org/10.33448/rsd-v9i7.4521

Barros, D. N., Almeida, C. V. de M., Ribeiro, D. S., Corrêa, M. M., \& Silva, S. P. da. (2018). Identification and characterization of starch in mango peel flour by FTIR and XDR. Ciências Agrárias, 1-10. https://doi.org/https://doi.org/10.31692/2526-7701.IIICOINTERPDVAGRO.2018.00141

Barros, S. de S., Oliveira, E. da S., Pessoa Jr, W. A. G., Rosas, A. L. G., de Freitas, A. E. M., Lira, M. S. de F., Calderaro, F. L., Saron, C., \& Freitas, F. A. (2021). Waste açaí (Euterpe precatoria Mart.) seeds as a new alternative source of cellulose: Extraction and characterization. Research, Society and Development, 10(7), 1-16.

Bergwitz, C., Eussen, S. R. B. M., Janssens, P. L. H. R., Visser, M., Carpenter, T. O., \& van Helvoort, A. (2021). Different elemental infant formulas show equivalent phosphorus and calcium bioavailability in healthy volunteers. Nutrition Research, 85, 71-83. https://doi.org/10.1016/j.nutres.2020.11.004

Bezerra, C. V. (2010). Caracterização e avaliação das propriedades funcionais tecnológicas da farinha de banana verde obtidas por secagem em leito de jorro. 88f. Dissertação de mestrado- Universidade Federal do Pará, Belém-PA.

Bezerra, J. A., \& Brito, M. M. de. (2020). Potencial nutricional e antioxidantes das Plantas alimentícias não convencionais (PANCs) e o uso na alimentação: Revisão. Research, Society and Development, 9(9), e369997159. https://doi.org/10.33448/rsd-v9i9.7159

Borges, A. de M., Pereira, J., \& Lucena, E. M. P. de. (2009). Caracterização da farinha de banana verde. Ciencia e Tecnologia de Alimentos, 333-339,abr./jun.

Borges, J. T. D. S., Ascheri, J. L. R., Ascheri, D. R., Nascimento, R. E. Do, \& Freitas, A. S. (2003). Propriedades de cozimento e carcterização físico-química de macarrão pré-cozido à base de farinha integral de quinoa (Chenopodium quinoa, Willd) e de farinha de arroz (Oryza sativa, L) polido por extrusão termoplástica. Boletim CEPPA, 21(2), 303-322. https://doi.org/10.5380/cep.v21i2.1167

Brancalione, G. (2021). Caracterzação de novas cultivares biofortificada de feijão (Phaseolus vulgaris), de mandicoca (Manihot esculenta) e de batata doce ( Ipomoea batatas ) para a utilização como farinha em produtos de panificação. Universidade Tecnológica Federal do Paraná- UTFPR, Pato Branco. 2021

BRASIL (2005). D.O.U. - Diário Oficial da União; Poder Executivo, de 23 de setembro de 2005. ANVISA - Agência Nacional de Vigilância Sanitária. Resolução RDC n 269, de 22 de setembro de 2005. Aprova o " Regulamento técnico sobre a ingestão diária recomendada (IDR) de proteína, vitaminas e minerais". 
BRASIL (2012).D.O.U.-Diário Oficial da União; Poder Executivo, de 12 de novembro de 2012. ANVISA - Agência Nacional de Vigilância Sanitária. Resolução RDC n 54, de 12 de novembro de 2012. Aprova o " Regulamento Técnico sobre Informação Nutricional Complementar ".

Caparino, O. A., Tang, J., Nindo, C. I., Sablani, S. S., Powers, J. R., \& Fellman, J. K. (2012). Effect of drying methods on the physical properties and microstructures of mango (Philippine "Carabao" var.) powder. Journal of Food Engineering, 111(1), 135-148. https://doi.org/10.1016/j.jfoodeng.2012.01.010

Carli, C. G. de. (2017). Farinhas comerciais de frutas: caracterização física, físico-química e análise de imagem digital. In Universidade Tecnológica Federal do Paraná. Dissertação(mestrado).120f.Universidade Tecnológica Federal do Paraná. Pato Branco-PR.

Cesar, A. L. T. M. de S., Cheim, L. M. G., Rossignoli, P. A., Rodrigues, L. J., Silva, F. F. da, Takeuchi, K. P., Carvalho, D. de M., \& Faria, A. M. de M. (2021). Características fisico-químicas e reológicas de amido de milho (Zea mays L.) de pipoca crioulo. Research, Society and Development, 10(13), e402101321394. https://doi.org/10.33448/rsd-v10i13.21394

Cheriegate, A. P. de S. C. (2012). Análise microestrutural da polpa da amora-preta (Rubbus spp) co-critalizada por sacarose. Universidade Federal do Paraná: Universidade Federal do Paraná.

Sá Mendes, N., Favre, L. C., Rolandelli, G., Ferreira, C. dos S., Gonçalves, É. C. B. d. A., \& Buera, M. del P. (2020). Flour from "fruits and vegetables" waste with addition of a South-American pepper (Capsicum baccatum) proposed as food ingredient. International Journal of Food Science and Technology, 55(3), 1230-1237. https://doi.org/10.1111/ijfs.14358

Souza, V. R., Pereira, P. A. P., Queiroz, F., Borges, S. V., \& Carneiro, J. de D. S. (2012). Determination of bioactive compounds, antioxidant activity and chemical composition of Cerrado Brazilian fruits. Food Chemistry, 134(1), 381-386. https://doi.org/10.1016/j.foodchem.2012.02.191

Estrela, Carlos (2018). Metodologia Científica: Ciência, Ensino, Pesquisa. Editora Artes Médicas

Faria, E. A., Leles, M. I. G., Ionashiro, M., Zuppa, T. de O., \& Antoniosi Filho, N. R. (2002). Estudo da estabilidade térmica de óleos e gorduras vegetais. Ecletica Quimica, 27, 1-7.

Fernandes, A. F. (2006). Utilização da farinha de cascade batata inglesa(Solanum tuberosum L.) na elaboração de pão integral [127f. Dissertação de mestradoUniversidade Ferderal de Lavras, Lavras-MG. https://doi.org/616.89-008.47:616-

Fernandes, A. F., Pereira, J., Germani, R., \& Oiano-Neto, J. (2008). Efeito da substituição parcial da farinha de trigo por farinha de casca de batata ( Solanum Tuberosum Lineu ). Ciência e Tecnologia de Alimentos, 28, 56-65,dez.

Figueirêdo, R. W. de, Maia, G. A., Holanda, L. F. F. de, Monteiro, J. C. S., \& Teixeira, E. A. M. (1986). Estudos do processamento e estabilidade da geléia de jenipapo (Genipa americana L.). Ciência e Agronomia, 17(1), 117-123,junho.

Franca, L. G. da, Holanda, N. V. de, Aguiar, R. A. C., Reges, B. M., Costa, F. B. da, Souza, P. A. de, Silva, Á. G. F. da, Sales, G. N. B., \& Moura, C. F. H. (2020). Elaboration and characterization of green banana flours. Research, Society and Development, 9(7). https://doi.org/http://dx.doi.org/10.33448/rsdv9i7.3798

Goula, A. M., \& Adamopoulos, K. G. (2006). Retention of ascorbic acid during drying of tomato halves and tomato pulp. Drying Technology, 24(1), 57-64. https://doi.org/10.1080/07373930500538709

Kebelmann, Katharina; Hornung, Andreas; Karsten, Ulf; Griffiths, Gareth.Intermediate pyrolysis and product identification by TGA and Py-GC/MS of green microalgae and their extracted protein and lipid components. Biomass and bioenergy. v. 49, p. 38-48, 2013

Krumreich, F., D`Ávila, R. F., Freda, S. A., \& Chim, J. F. (2016). Análises físico-químicas e estabilidade de compostos bioativos presentes em polpa de uvaia em pó obtidos por métodos de secagem e adição de maltodextrina e goma arábica. Revista Thema, 13, 4-17. https://doi.org/http://dx.doi.org/10.15536/thema.13.2016.4-17.351

Leonel, M. (2007). Análise da forma e tamanho de grânulos de amidos de diferentes fontes botânicas. Ciência e Tecnologia de Alimentos, 27(3), 579-588. https://doi.org/10.1590/S0101-20612007000300024

Lima, B. N. B., Cabral, T. B., Neto, R. P. C., Tavares, M. I. B., \& Pierucci, A. P. T. (2012). Estudo do amido de farinhas comerciais comestíveis. Polímeros, 22(5), 486-490. https://doi.org/http://dx.doi.org/10.1590/S0104-14282012005000062

Melo Neto, B. A., Fernandes, B. S., Fornari Júnior, C. C. M., Bonomo, R. C. F., Almeida, P. F., \& Pontes, K. V. (2016). Thermal-morphological characterisation of starch from peach-palm (Bactris Gasipaes kunth) fruit (Pejibaye). International Journal of Food Properties, 20(5), 1007-1015. https://doi.org/10.1080/10942912.2016.1192645

Monteiro, A. A. de S., Richter, A. R., Maciel, J. da S., Feitosa, J. P. A., Paula, H. C. B., \& Paula, R. C. M. de. (2015). Efeito da modificação química na solubilidade e intumescimento de microesferas à base de goma do cajueiro carboximetilada e quitosana. Polímeros, 25, 31-39. https://doi.org/10.1590/01041428.1779

Morais, J. L., Souza, F. P., Silva, T. M. C. F., \& Oliveira, M. E. G. (2016). Desenvolvimento e caracterização de doces pastosos adicionados de especiarias obtidos a partir da polpa de jenipapo ( Genipa americana L .). XXV Congresso Brasileiro de Ciência e Tecnologia de Alimentos, 1-6,outubro.

Moura, L. C. de. (2016). Desenvolvimento de bebidas lácteas com polpa de goiaba e farinha da casca de jabuticaba e cinética da secagem e composição físicoquímica dos resíduos. In Instituto Federal Gioano. 73f. Dissertação de mestrado-Instituto Federal Goiano, Rio Verde-GO.

Oliveira, A. L. de, Almeida, E. de, Silva, F. B. R. da, \& Nascimento Filho, V. F. (2006). Elemental contents in exotic Brazilian tropical fruits evaluated by energy dispersive X-ray fluorescence. Scientia Agricola, 63(1), 82-84,jan./feb. https://doi.org/10.1590/S0103-90162006000100013

Pereira, A., Shitsuka, D., Parreira, F., \& Shitsuka, R. (2018). Metodologia da Pesquisa Cientifica. UFSM (1st ed.). UFSM, NTE.ebook 
Rinaldi, M. M., Lima, T. A. De, \& Palmiro, D. A. R. (2010). Caracterização Física de Frutos de Mamão e Química de Cascas e Sementes. Embrapa CerradosBoletim de Pesquisa e Desenvolvimento-263, 17.

Rambo, Magale K.D., \& Ferreira, M. M. C. (2015). Determination of cellulose crystallinity of banana residues using near infrared spectroscopy and multivariate analysis. Journal of the Brazilian Chemical Society, 26(7), 1491-1499. https://doi.org/10.5935/0103-5053.20150118

Rambo, Magale Karine Diel, Rambo, M. C. D., Almeida, K. J. C. R., \& Alexandre, G. P. (2015). Estudo de análise termogravimétrica de diferentes biomassas lignocelulósicas utilizando a análise por componentes principais. Ciência e Natura, 37(3), 862-868,set./dez.

Ratti, C. (2001). Hot air and freeze-drying of high-value foods: A review. Journal of Food Engineering, 49(4), 311-319. https://doi.org/10.1016/S02608774(00)00228-4

Ribeiro, J. S., Andrade, G. A. V, Donato, L. B., Lobo, N. Q. S., Tapia, D. M. T., \& Silva, M. V. (2016). Caracterização química da farinha de jenipapo (Genipa americana L .): curva de secagem e estabilidade dos carotenoides totais. XXV Congresso Brasileiro de Ciência e Tecnologia de Alimentos, 1-7.

Schutten, J. C., Joris, P. J., Minović, I., Post, A., van Beek, A. P., de Borst, M. H., Mensink, R. P., \& Bakker, S. J. L. (2021). Long-term magnesium supplementation improves glucocorticoid metabolism: A post-hoc analysis of an intervention trial. Clinical Endocrinology, 94(2), 150-157. https://doi.org/10.1111/cen.14350

Silva, G. S. da, Trindade, F. C. da S., Souza, K. C. de, Caetano, V. F., Almeida, Y. M. B. de, \& Vinhas, G. M. (2021). Avaliação da influência da incorporação do óleo de coco em membranas de Celulose Bacteriana. Research, Society and Development, 10(1), e52910112002. https://doi.org/10.33448/rsd-v10i1.12002

Silva, da. J.; Queiroz, A. C. de. Análise de alimentos: métodos químicos e biológico. 3. ed. Viçosa, MG: UFV, 2002.

Silva, S. A. da, Souza, A. G., Conceição, M. M. da, Alencar, A. L. S., Prassad, S., \& Carvalheiro, J. O. (2001). Estudo termogravimétrico e calorimétrico da algaroba. Revista Química Nova, 24(4), 460-464.

Silvio, V. M. de, Farias, L. C. B., Medeiros, J. S., Santos, L. S. dos, Leão, P. V. T., Oliveira, L. A. de, Carmo, R. M. do, Cunha, J. V. T. da, Azzi, M. V. C., Caliari, M., \& Silva, M. A. P. da. (2020). Physical and chemical parameters of saffron and use as a color in Greek yogurt flavored with passion fruit jelly. Research, Society and Development, 9(7), e117953244. https://doi.org/http://dx.doi.org/10.33448/rsd-v9i5.3244

Souza, C. D. R. de, \& Silva, K. de C. da. (2021). Energy potential of waste from Brazil nut ( Bertholletia excelsa H . B . K .) for production of activated carbon. Research, Society and Development, 10(2), e53310212698. https://doi.org/http://dx.doi.org/10.33448/rsd-v10i2.12698

Stone, M. S., Martin, B. R., \& Weaver, C. M. (2021). Short-Term RCT of Increased Dietary Potassium from Potato or Potassium Gluconate: Effect on Blood Pressure, Microcirculation, and Potassium and Sodium Retention in Pre-Hypertensive-to-Hypertensive Adults. Nutrients, 13, 1610. https://doi.org/https://doi.org/10.3390/nu13051610

TABELA BRASILEIRA DE COMPOSIÇÃO DE ALIMENTOS- TACO, NEPAUNICAMP. 4. ed. rev. ampl., Campinas-SP, 2011 , p.161.

Tavares, S. A., Pereira, J., Guerreiro, M. C., Pimenta, C. J., Pereira, L., \& Missagia, S. V. (2011). Caracterização físico-química da mucilagem de inhame liofilizada. Ciência e Agrotecnologia, 35(5), 973-979, set./out.

Tontul, I., \& Topuz, A. (2017). Spray-drying of fruit and vegetable juices: Effect of drying conditions on the product yield and physical properties. Trends in Food Science and Technology (Vol. 63). https://doi.org/10.1016/j.tifs.2017.03.009

Torres, K. da S., Salvador, G. D., Batista, M. C. C., Mendes, I. L., Batista, N. K. C., Azevedo, M. A. F. de, Cavalcante, R. M. S., Macedo, L. L. B. de S., \& Moura, M. S. B. de. (2020). Individualized supplementation of iron and folic acid for adult pregnant women. Research, Society and Development, 9(7), e2819119740. https://doi.org/http://dx.doi.org/10.33448/rsd-v9i11.9740

Verna, G., Sila, A., Liso, M., Mastronardi, M., Chieppa, M., Cena, H., \& Campiglia, P. (2021). Iron-Enriched Nutritional Supplements for the 2030 Pharmacy Shelves. Nutrients, 13, 378. https://doi.org/https://doi.org/10.3390/nu13020378

Zartorelli, M. F. (2014). Produção e caracterização de manga desidratada em pó por diferentes processos de secagem. 165 p.Tese (doutorado)-Universidade Federal de Santa Catarina, Florianópolis-SC.

Zhang, P., \& Hamaker, B. R. (2012). Banana starch structure and digestibility. Carbohydrate polymers, v.87, n.2, p.1552-1558.

Zuidam, N. J., \& Nedovic, V. (2012). Encapsulation Technologies for Active Food Ingredients (N. J. Zuidan \& V. A. Nedovic (eds.)). Springer. https://doi.org/10.1016/B978-0-1238-2018-1.00007-0 